\title{
Soil Physico-Chemical Property Characterisation Along with Different Land Use System in Gurage Zone, Southern Ethiopia
}

\author{
Kedir Jemal*, Henok Tesfaye \\ Wondo Genet Agricultural Research Center, Ethiopian Institute of Agricultural Research, Shashemene, Ethiopia
}

Email address:

kedirjemal32@yahoo.com (K. Jemal)

${ }^{*}$ Corresponding author

\section{To cite this article:}

Kedir Jemal, Henok Tesfaye. Soil Physico-Chemical Property Characterisation Along with Different Land Use System in Gurage Zone, Southern Ethiopia. Modern Chemistry. Vol. 8, No. 3, 2020, pp. 40-47. doi: 10.11648/j.mc.20200803.12

Received: June 23, 2020; Accepted: September 18, 2020; Published: November 16, 2020

\begin{abstract}
Nowadays the impact of land use change on different natural and manmade resources including soil resources is getting increased attention globally. Information about impact of land use systems on soil physico-chemical properties is crucial for best land management practices. This study was, therefore, conducted to assess the impact of land use/land cover on the physicochemical properties of soils of wudma area, southern Ethiopia. The land use systems studied included grazing land, cultivated land, eucalyptus plantation and natural forest. The research was superimposed on land use systems that were located nearby on similar soil. Undisturbed core and disturbed composite soil samples were collected randomly with four replications for each land use system. The influence of land use systems on soil properties were analysed using the analysis of variance general linear model procedure of SAS software. Mean differences due to land use, were identified using The Least Significant Difference (LSD) test after differences were found statistically significant. The results showed that most of the soil physicochemical properties varied with land use systems. For instance soil texture, bulk density, $\mathrm{pH}\left(\mathrm{H}_{2} \mathrm{O}\right), \mathrm{OM}$, Total N, available $\mathrm{p}, \mathrm{CEC}$, exchangeable $\mathrm{K}$, studied were significantly affected $(\mathrm{P} \leq 0.05$ and/or $\mathrm{P} \leq 0.01)$ by land use. In contrast, silt, total porosity, exchangeable $\mathrm{Na}$, carbon to nitrogen ratios, was not significantly $(\mathrm{P}>0.05)$ different due to land use. Generally, comparisons between cultivated on one hand and the forest, eucalyptus and grazing lands on the other revealed a highly significant difference on soil fertility parameters. For instance the highest mean values of $\mathrm{pH}, \mathrm{OM}$ and CEC, TN, Ca and $\mathrm{Na}$ were observed in the surface of forest land soil with $(6.4,8.1,75 \mathrm{cmol}(+) \mathrm{kg}-1,0.4,60,0.84 \mathrm{cmol}(+) \mathrm{kg}-1)$ were observed under the forest land as compared to the lowest values $(5.6,3.8,35 \mathrm{cmol}(+) \mathrm{kg}-1,0.19,14$ and $0.48 \mathrm{cmol}(+) \mathrm{kg}-1)$ in the cultivated land respectively. The results of study showed that forest clearing and subsequently cultivation and tillage practices resulted in the decline of the soil quality and these changes effects on soil sensitivity to degradation and erosion. Therefore, reducing the intensity of cultivation and adopting integrated soil fertility management could maintain the existing soil condition and replenish the degraded soil properties of the area.
\end{abstract}

Keywords: Land Use System, Soil, Physico-Chemical Properties

\section{Introduction}

Land use is defined as the arrangements, activities and inputs people undertake in a certain land cover type to produce, change or maintain it [28]. Successful agriculture requires the sustainable use of soil resource because soils can easily loose its quality and quantity within a short period for many reasons [14]. For this reason, agricultural practice requires basic knowledge of sustainable use of the land. A success in soil management to maintain the soil quality depends on an understanding of how the soil responds to agricultural practices over time [3]. Recent interest in evaluation the quality of our soil resource has been therefore simulated by increasing awareness that soil is critically important component of the earth's biosphere, functioning not only in the production of food and fiber but also in the maintenance of local, regional, and worldwide environmental quality [35].

Land use/land cover (LULC) changes influence the 
biogeochemistry, hydrology, and climate of the earth. Elucidating the impact of LULC at the local to regional scales on soil quality status is not direct but rather complex to guarantee any generalizations. The conversion of Forest Reserve to other land uses in recent times has caused many complex changes in the forest ecosystem whose impact raises diverse ecological problems [17]. Transformation of one land use system into another system and different management practices can affect soil structure, soil organic carbon and other nutrients reserve [36, 43]. Also compared croplands, forestlands and grazing lands and found that soil organic $\mathrm{C}$ and total $\mathrm{N}$ decreased in croplands as compared to forestlands. Deforestation increases soil erosion because of the reduction of the soil stability, which leads to floods, drought and natural ecosystem degradation [2].

Moreover successful crop production requires the sustainable use of the soil resource, because of the decline in soil quantity within short period. Hence, it is apparent that restoration of marginal land has high priority. However, it is possible only through a good understanding of the physical, chemical and biological properties and the resilience characteristics of the soils [4]. Currently the study area is facing the problem of deforestation, over grazing, poor soil management and severe erosion. For combating and minimizing the ongoing soil degradation and enhance land productivity through sustainable use of soil resources, it requires understanding the soil physicochemical properties of different land use systems [9]. However, there is no scientifically studied information in the study area.

Agriculture is the foundation of the economy of the study area as elsewhere in Ethiopia. The study area is endowed with potentially rich natural resources, of which land is the principal one. However, its productivity is continuously declining, due to continuous cultivation without adequate management methods [24]. Rapid increase in demands the production of ever-increasing quantity of food, fibre and fuel from the land. To meet these needs, vast tract of land are being farmed more intensively, and large areas of grasslands are being overgrazed and degraded. Additionally, new and often marginal land is being brought into production. Therefore, land must be carefully managed, if its productivity is to be maintained or increased. If it is not well managed, or used in a way that is beyond its potential, soil degradation will inevitably occur [11].

It is important to establish land use system that allow for the demands of increasing population while conserving the soil fertility in the long term. Soil resources are finite and non-renewable over human periods and are prone to degradation by misuse and mismanagement. However, the general recognition of the threat from land degradation on land productivity and ecosystem sustainability, there is no studies have been conducted in the study area to quantify the proper indicators for evaluating and monitoring soil quality. Therefore, this study will be undertaken to demonstrate the effect of four land use systems on physicochemical properties of the soil and to assess land degradation in the study area. This will help decision maker and different stakeholders to have proper land use [23].

\subsection{General Objective}

The general objective of this study is to evaluate the effect of selected land use types on soil properties of wudma area, southern Ethiopia.

\subsection{Specific Objectives}

1) To determine the status of selected soil physical and chemical properties of the study area.

2) To examine the effect of different land use systems on selected soil physical and chemical properties of the study area

\section{Materials and Methods}

\subsection{Description of the Study Area}

The study was conducted at the wudma Watershed that is located in Gurage Zone, District of the South Nation and Nationalities and people's regional state of Ethiopia. Geographically, the study site lies at $11^{\circ} 43.8^{\prime}$ to $11^{\circ} 45^{\prime} \mathrm{N}$ latitude and $38^{\circ} 08^{\prime}$ to $38^{\circ} 10^{\prime} \mathrm{E}$ longitude and at an altitude ranging from 1800 to 3662 meters above sea level (masl). It covers an area of about 54,500 (ha). The topography of the woreda is generally characterized by flat plain $45 \%$, steep $10 \%$, rugged mountains, $30 \%$ and gentle slope $15 \%$. The relief of the study region varies from $1800 \mathrm{~m}$ found in the western part and high up to $3,662 \mathrm{~m}$ above sea level in the eastern part. The agro ecology is Weina Dega (10\%), Dega $(80 \%)$ and wurch $(10 \%)$. The duration and pattern of rainfall influences the farmers' cropping cycles and practices at the wudma area and the highlands in the District as a whole. The area is characterized by Uni-modal rainfall pattern, which extends from June to September and increases gradually in Frequency to reach the maximum in August and then decline rapidly after the peak starting in September. The mean annual rainfall distribution ranges between $900 \mathrm{~mm}$ up to $1200 \mathrm{~mm}$ and mean annual temperature ranges between 6 and $16^{\circ} \mathrm{C}$.

\subsection{Site Selection and Soil Sampling}

Four land use systems (natural forest, grazing land cultivated land and Eucalyptus plantation) were considered for the study. Under each land use, soil samples were obtained at constant depth $0-30 \mathrm{~cm}$, following a $\mathrm{w}$ layout design. During the collection of the samples, the dead plants, furrow, wet spots, area near the trees and compost pits were avoided. for reducing errors that will occur during analysis as well as minimizing differences in result that may come from the addition of organic matter in to the soil. Approximately 1 $\mathrm{kg}$ of composite sample were collected from each land use and placed in to plastic bags.

From each adjacent land uses, composite soil samples were made by collecting 15-20 random soil sub samples within $30 \mathrm{~cm}$ depth, using hand auger in four replication. There were sixteen composite soil samples (four land use 
types $\mathrm{x}$ four replication $\mathrm{x}$ one soil depth, 0-30 cm). Moist soil samples were air dried as soon as possible before being bagged and sent to soil testing laboratory. Drying was best accomplished by spreading each sample on paper to air at room temperature. Then it was crushed, homogenized, and passed through a $2 \mathrm{~mm}$ sieve to remove stones, roots, and large particles. For the determination of bulk density, sixteen undisturbed soil samples were collected using core sampler.

\subsection{Soil Lapratory Analysis}

Soil texture was analysed by the Bouyoucous hydrometer method [4], after OM was destroyed or burned by using hydrogen peroxide $\left(\mathrm{H}_{2} \mathrm{O}_{2}\right)$, soil particles dispersed and disintegrated by sodium carbonate $\left(\mathrm{Na}_{2} \mathrm{CO}_{3}\right)$ and sodium hexametaphosphate $\left(\mathrm{NaPO}_{3}\right)$ in distilled water and finally using amyl alcohol to destroy the soil solution foam. After the particle size distributions were determined in percent, the textural class of the soil could obtain by using USDA soil textural triangle classification system [40]. The bulk density (BD) of the soil was measured from undisturbed soil samples collected using a core sampler after drying the core samples in an oven at $105^{\circ} \mathrm{C}$ [48]. The total porosity of soil samples was estimated from the values of bulk density (BD) and particle density (PD) (assuming an average particle density of mineral soil is $2.65 \mathrm{~g} \mathrm{~cm}-3)$. Then the total porosity (TP) was calculated as, TP $(\%)=(1-$ Bulk density/Particle density) * (100).

The $\mathrm{pH}$ of the soils was measured in water $\left(\mathrm{H}_{2} \mathrm{O}\right)$ suspension in a 1:2.5 (soil: liquid) by $\mathrm{pH}$ meter, whereas electrical conductivity was measured by a conductivity meter [45]. To determine organic carbon, the [44] method was used in which the carbon was oxidized under standard conditions with potassium dichromate $\left(\mathrm{K}_{2} \mathrm{Cr} 2 \mathrm{O} 7\right)$ in sulphuric acid solution. Finally, the organic matter content of the soil was calculated by multiplying the organic carbon percentage by 1.724 following the assumptions that OM is composed of $58 \%$ carbon. The total nitrogen content in soils was determined using the Kjeldahl digestion, distillation and titration method by oxidizing the $\mathrm{OM}$ in concentrated sulphuric acid solution $\left(0.1 \mathrm{~N}_{2} \mathrm{SO} 4\right)$ as described by [48]. Then after, C: $\mathrm{N}$ was calculated by dividing organic carbon to total nitrogen.

Exchangeable bases ( $\mathrm{Na}, \mathrm{K}, \mathrm{Mg}$ and $\mathrm{Ca}$ ) were determined after extracting the soil samples by ammonium acetate $\left(1 \mathrm{~N} \mathrm{NH}_{4} \mathrm{OAc}\right)$ at $\mathrm{pH}$ 7.0. The available $\mathrm{P}$ was calculated by the Olsen method-using sodium bicarbonate $\left(0.5 \mathrm{M} \mathrm{NaHCO}_{3}\right)$ as an extraction solution [25]. Exchangeable $\mathrm{Na}$ and $\mathrm{K}$ were analysed by flame photometer while $\mathrm{Ca}$ and $\mathrm{Mg}$ in the extracts was analysed using atomic absorption spectrophotometer (AAS) as described by Rowell [46]. Cation exchange capacity was estimated titrimetric ally by distillation of ammonium that could be displaced by sodium from $\mathrm{NaCl}$ solution Chapman, 1965. Percent base saturation was calculated by dividing the sum of the charge equivalents of the base forming cations $(\mathrm{Na}, \mathrm{K}, \mathrm{Mg}$ and $\mathrm{Ca}$ ) by the $\mathrm{CEC}$ of the soil and multiplying by 100 [15].

\subsection{Statistical Analysis}

One-way analyses of variance (ANOVA) procedures was used to compare the effects of different land use/land cover on chemical and physical properties of soil using General Linear Model (GLM) of using SAS software version 9.3 (SAS, 2013). Separation of the means of the soil properties was performed using LSD test $(\mathrm{p}<0.05)$.

\section{Results and Discussion}

\subsection{Impact of Land Use on Selected Physical Properties of the Soils}

\subsubsection{Texture}

According to the results of analysis of variance (ANOVA) revealed that Textural differences were observed among the land use types particularly due to the changes in the clay and sand fractions which varied significantly (Table 2).

The forestland soils were dominated by sand, grazing land, cultivated and eucalyptus were dominated by clay fractions. The sand fraction varied significantly across the land uses $(\mathrm{P} \leq 0.05)$. As indicated in Table 2 , the sand content was highest in the forestland $(45.5 \%)$ while the lowest was observed in the grazing land (16\%). Similarly, the clay fraction was influenced by changes in land use types $(\mathrm{P} \leq 0.05)$ which are attributed to the varying soil management practices [1].

The average clay fraction was found to be highest in the soils of the grazing land $(60 \%)$ whereas it was lowest in the forestlands $(35 \%)$. On the other hand, silt showed nonsignificant $(\mathrm{P}>0.05)$ difference among the land uses (Table 2$)$. These same reasons were also used by several authors, $[34,35$, 10]. Texture is an inherent soil property; however, management Pedogeologic processes such as erosion, deposition, illuviation and weathering which are shaped by management practices can alter the texture of soils [4].

Table 1. Mean values of particle size distribution and bulk density as influenced by the different land uses.

\begin{tabular}{|c|c|c|c|c|c|c|}
\hline \multirow{2}{*}{ Land Use } & \multicolumn{3}{|c|}{ Particle size distribution (\%) } & \multirow{2}{*}{ Textural class } & \multirow{2}{*}{$\mathrm{Pb}\left(\mathrm{gcm}^{3}\right)$} & \multirow{2}{*}{ Total porosity } \\
\hline & Sand & silt & clay & & & \\
\hline Forest land & $45.5^{\mathrm{a}}$ & 19.5 & $35^{\mathrm{c}}$ & SCL & $0.823^{\mathrm{b}}$ & 64 \\
\hline Grazing land & $16^{\mathrm{c}}$ & 24 & $60^{\mathrm{a}}$ & Clay & $1.103^{\mathrm{a}}$ & 60.5 \\
\hline Eucalyptus & $35^{b}$ & 21.5 & $43.5^{\mathrm{c}}$ & $\mathrm{SC}$ & $1.06^{\mathrm{a}}$ & 64 \\
\hline Crop land & $31^{\mathrm{b}}$ & 22 & $47^{\mathrm{b}}$ & $\mathrm{SC}$ & $1.100^{\mathrm{a}}$ & 58.7 \\
\hline $\operatorname{LSD}(0.05)$ & 8.612 & NS & 10 & 0.22 & 9.1 & \\
\hline CV $(\%)$ & 17.5 & 13.9 & 14 & 14.4 & 9.2 & \\
\hline
\end{tabular}

Means within column followed by the same letter are not statistically different from each other at P $>0.05$; LSD $=$ least significant difference; NS = nonsignificant; $\mathrm{CV}=$ coefficient of variation. $\mathrm{Pb}=$ bulk density 


\subsubsection{Bulk Density}

Bulk density $\left(\mathrm{g} / \mathrm{cm}^{3}\right)$ differed significantly $(\mathrm{P}<0.05)$ between the soils under natural forest and all the other land use/land cover systems. The highest BD was found in the grazing land (1.103) followed by the soil under cropland. In contrast, the lowest BD values of (0.823) were observed under forestland. Bulk density was higher in grazing and cultivated lands as compared to forest and eucalyptus land. It can be suggested that deforestation and subsequent tillage practices resulted in soil compaction, low infiltration and hence increased in bulk density for surface. Similar finding has been reported in other areas around the world [47]. The findings from the study confirm those of [47], who concluded that Eucalyptus spp. Plantations increased soil bulk density more than the native forest in Botswana.

\subsubsection{Total Porosity}

The total porosity was not significantly affected by different land uses $(\mathrm{P} \leq 0.05)$, (Table 2). The average total porosity of the forest, the grazing, eucalyptus and the cultivated lands were $64,60.5,64,58.7 \%$, respectively (Table 2). $\mathrm{P}$ was high in forestland use relatively to other land use due to the high organic matter content and earthworms that play an important role in the decomposition of organic material [6].

It has been reported that the decrease in bulk density with organic amendments is directly related to the increased porosity, which is related to the improved soil aggregation. In addition, pore spaces are increasing by the movements of the grass roots hence increase the voids between soil particles. The values of soil porosity of these land uses were ranging from bad soil porosity to very good soil porosity.

\subsection{The Impact of Land Use on Selected Chemical Properties of the Soils}

\subsubsection{Soil pH}

The soils $\mathrm{pH}-\mathrm{H}_{2} \mathrm{O}$ value was significantly affected by land use $(\mathrm{P} \leq 0.05)$ the highest (6.4) and the lowest (5.6) soil pH$\mathrm{H}_{2} \mathrm{O}$ values were recorded under the forest and the cultivated lands, respectively (Table 3 ). The low $\mathrm{pH}$ values in cropland could be due to high tillage frequency, high rates of inorganic fertilizer applications (especially ammonium fertilizers), and low amount of organic matter because of erosion or due to aluminum toxicity [16].

Low soil $\mathrm{pH}$ impedes the $\mathrm{CEC}$ of the soil by altering the surface charge of colloids (finest clay particles and soil organic matter [22]. Low CEC implies that soil will have less exchangeable cations required as crop nutrients; nutrients are weekly adsorbed and hence may be leached out. According to [26], soil $\mathrm{pH}$ level $<5.0$ is rated as very strong acid, 5.15.5 strong acid, 5.6- 6.0 moderate acidic and, 6.1- 6.5 is rated as slightly acidic. Based on the above ratings, soils of the study area were forest land and grazing qualify slightly acidic while the eucalyptus and cultivated lands qualify for moderate acidic status of soil $\mathrm{pH}[29]$.

\subsubsection{Organic Matter}

The soil organic matter OM content of forest land (8.1) was significantly $(\mathrm{P}<0.005)$ higher than other lands uses and in cultivated land is the lowest (Table 3). Non-significant ( $\mathrm{P}>$ 0.05 ) difference was observed between eucalyptus plantation, grazing land and crop land (Table 3 ). Since soil organic matter is composed chiefly of carbon, hydrogen, oxygen, nitrogen and smaller quantities of sulphur and other elements [12], it is an important indicator of soil and land health as it integrates several inherent soil properties and responds strongly to landuse change and land degradation processes [33]. Thus, the highest organic fraction of forestland is potentially with the highest reservoir for plant essential nutrients of nitrogen, phosphorus, and sulphur [41] compared to grazing and cultivated lands [13].

This general truth was assured by different individuals [33, 10] who obtained lower levels of soil OM under cultivated, grazing or degraded land than in the forest land as well as in the cultivated and degraded land use types than in the grazing land. Besides this, leaching that can be attributed to the relatively high sand content and the resultant light texture of soils might be the cause of OM reduction in the cultivated land. Accordingly, the findings of this study are in agreement with the results of similar recent studies reported by $[10,35$, and 30]. According to the standard rating of $\mathrm{OM}$ as indicated by [26], the soils of the forestland of wudma area qualify for very high and the remaining lands qualifies for high status soil OM $[31,38]$.

\subsubsection{Total Nitrogen and Carbon to Nitrogen Ratio}

The total $\mathrm{N}$ content of the soils was significantly $(\mathrm{P} \leq 0.05)$ affected by land use. The total $\mathrm{N}$ was highest $(0.4 \%)$ on the forest land and lowest $(0.19 \%)$ under the cultivated land (Table 3). Total $\mathrm{N}$ declined with shift of land uses from natural forest into agricultural fields. Large losses of total $\mathrm{N}$ (decrease by $46.77 \%$ ), in the continuously cropped fields compared to the forest land could be attributed to rapid mineralization of soil OM following cultivation, which disrupts soil aggregates, and thereby increases aeration and microbial accessibility to OM $[30,10]$.

It is apparent that conversion of natural forest into other land-use results in a decline of total $\mathrm{N}$ in the soil as found in the present study. An addition of a relatively higher plant residue and minimal rate of decomposition might be responsible for higher amount of total $\mathrm{N}$ in natural forest soil as described by $[27,28,7]$ stated that the higher total $\mathrm{N}$ was obtained under forest land compared to the adjacent grazing and cultivated lands. The low level of organic matter and total $\mathrm{N}$ in cultivated land soil suggests degrading effects due to long history of crop cultivation. Cropping had indicated reduction of total $\mathrm{N}$ contents. The reduction in the total $\mathrm{N}$ is entirely accounted for by the decline of the organic matter through the continuous cropping of the soils [8].

In accordance with $\mathrm{C}: \mathrm{N}$ ratio, significant difference was not observed among land use types (Table 3 ). However, numerically the $\mathrm{C}: \mathrm{N}$ ratio was higher under forestland as 
compared to cultivated land. The reason obviously could be the higher contents of soil OM in case of forestland. They also suggested that the optimum range of the $\mathrm{C}: \mathrm{N}$ is about $10: 1$ to $12: 1$ that provides nitrogen in excess of microbial activities. Accordingly, the $\mathrm{C}: \mathrm{N}$ of the soil across the land use types under the study area were considered to be within the optimum range in all land use types. This indicates that the presence of suitable mineralization processes of soil organisms $[18,37]$.

Table 2. Mean values of $p H$, soil organic matter (OM), total $N(T N), C: N$ ratio as influenced by the different land use.

\begin{tabular}{llllll}
\hline Land use & $\begin{array}{l}\mathbf{p H} \\
\left(\mathbf{H}_{\mathbf{2}} \mathbf{O}\right)\end{array}$ & $\begin{array}{l}\mathbf{O M} \\
\mathbf{( \% )}\end{array}$ & $\mathbf{T N}(\mathbf{\%})$ & $\begin{array}{l}\mathbf{C}: \mathbf{N} \\
\text { ratio }\end{array}$ & $\begin{array}{l}\text { Available } \mathbf{P} \\
(\mathbf{p p m})\end{array}$ \\
\hline Forest & $6.4 \mathrm{a}$ & $8.1 \mathrm{a}$ & $0.4 \mathrm{a}$ & $11.8 \mathrm{a}$ & $13.2 \mathrm{a}$ \\
Grazing & $6.3 \mathrm{a}$ & $4.7 \mathrm{~b}$ & $0.23 \mathrm{~b}$ & $11.6 \mathrm{a}$ & $19.2 \mathrm{a}$ \\
Eucalyptus & $5.8 \mathrm{~b}$ & $4.6 \mathrm{~b}$ & $0.2 \mathrm{~b}$ & $11.7 \mathrm{a}$ & $20.8 \mathrm{a}$ \\
Crop land & $5.6 \mathrm{~b}$ & $3.8 \mathrm{~b}$ & $0.19 \mathrm{~b}$ & $11.7 \mathrm{a}$ & $10.8 \mathrm{a}$ \\
LSD (0.05) & 0.25 & 2.3 & 0.11 & 0.31 & 11 \\
CV (\%) & 2.7 & 23 & 27 & 1.7 & 43.2 \\
\hline
\end{tabular}

Means within column followed by the same letter are not statistically significant from each other at $\mathrm{P}>0.05$. LSD $=$ Least significant difference; $\mathrm{NS}=$ Non significant; $\mathrm{CV}=$ Coefficient of variation.

\subsubsection{Available Phosphorus}

The ANOVA results show no significant difference for different land-use/cover. Mean comparison test of available phosphorus amongst the land use the soils under eucalyptus plantation had the highest mean soil available phosphorus concentrations $(20.8 \mathrm{ppm})$ followed by those under grazing and forest land use system $19.2 \mathrm{ppm}$ and $13.2 \mathrm{ppm}$ respectively, while those under crop land use had the lowest value $10.8 \mathrm{ppm}$ (Table 3). It can be concluded here that residue ash may have enhanced the $\mathrm{P}$ concentrations under eucalyptus plantation and cow dung may have enhanced the $\mathrm{P}$ concentrations in grazing area. Our result agree with [39], The available $\mathrm{P}$ contents of the soils under all land uses were generally high, although cultivated land showed variation in available $\mathrm{P}$ content from the forestland which obviously could be due to crop mining, crop residue removal and erosion $[25,21,42]$.

\subsubsection{Cation Exchange Capacity and Percentage Base Saturation}

The analysis of variance results revealed that the cation exchange capacity (CEC) of the soils in the study area was significantly $(\mathrm{P} \leq 0.05)$ affected by the land use types. The CEC means values under forest, grazing, eucalyptus and croplands were 75, 57, 49 and, 35 cmolc kg-1, respectively (Table 3). The result of this study indicated that the CEC of the forestland was significantly higher than the adjacent three land use types The CEC values in the cropland uses decreased mainly due to the reduction in OM content. CEC of soil is determined by the relative amounts and/or type of the two main colloidal substances; humus and clay. Organic matter particularly plays important role in the soil exchange processes because it provides more negatively charged surfaces than clay particles do [5].

This result is in agreement with the findings of [39] who suggested that the CEC of soil was higher in forestland compared to that of the adjacent grazing and cultivated lands. Moreover, [27] reported that the CEC of soil was higher in the subsurface of soil layer under the adjacent forest, cultivated and grazing lands. As per the ratings CEC recommended by [42], the CEC value of soil under the grazing, cultivated and eucalyptus plantation land were in the range of high rate while it was rated as very high under the forest land.

Percentage base saturation was significantly $(\mathrm{P}>0.05)$ affected by land use (Table 2). The highest (99\%) and the lowest $(62.64 \%)$ values of PBS were recorded under the forest and the cultivated lands, respectively. In general, processes that affect the extent of basic cations also affect percent base saturation

\subsubsection{Electrical Conductivity}

Effects of land use change on electrical conductivity EC values ranged from $0.014 \mathrm{ds} \mathrm{m}-1$ under eucalyptus land use systems to 0.023 under forest vegetation. Generally, the results showed no significant difference in land use (Table 3). Therefore, the conversion of forest to cultivated land decreases EC in the study area. These results are in line with the findings of [27] who reported that changing forest to cultivated land increased EC values in their area of study due to high application rates of chemical fertilizers [19.20].

Although EC represents soil soluble salt components, it is believed that the use of basic chemical fertilizer such as ammonium phosphate and urea under farmlands in our study area did not lead to higher EC values above normal (EC > $0.15 \mathrm{mS} / \mathrm{cm}$ will affect plant growth and development). Therefore, farmers must avoid complete reliance on chemical inputs but continue to rely more on organic fertigation to keep $\mathrm{EC}<0.15$ in soils [32].

\subsubsection{Basic Exchangeable Cations}

The content of exchangeable calcium (Ca) was significantly $(\mathrm{P}>0.05)$ affected by land uses, (Table 3$)$. The presence of such significant variation on exchangeable $\mathrm{Ca}$ could be triggered from different management practice, way of land utility, and the various imbalances proportional of soil texture and OM. The mean values of exchangeable $\mathrm{Ca}$ under the forest, grazing, eucalyptus and the cultivated lands were $60,38,21$ and $14 \mathrm{cmol}(+) \mathrm{kg}-1$ respectively (Table 3). Exchangeable magnesium $(\mathrm{Mg})$ content was significantly $(\mathrm{P}>0.05)$ affected by land use. The mean exchangeable $\mathrm{Mg}$ value was highest $(11 \mathrm{cmol}(+) \mathrm{kg}-1)$ under the forest land and lowest $(5 \mathrm{cmol}(+) \mathrm{kg}-1)$ on the cultivated land. The lowest values obtained on the cultivated land could be related to the influence of intensity of cultivation and abundant crop harvest with little or no use of input.

Exchangeable $\mathrm{K}$ content was significantly $(\mathrm{P} \leq 0.05)$ affected by land use types. Exchangeable $\mathrm{K}$ content was highest $(2.13 \mathrm{cmol}(+) \mathrm{kg}-1)$ in the forestland and lowest $(0.9$ cmol (+) kg-1) in the eucalyptus land (Table 3). The highest content in the forestland was related with its high $\mathrm{pH}$ value and was in agreement with study results reported by [34] that high $\mathrm{K}$ was recorded under high $\mathrm{pH}$ tropical soils. Generally, 
the lower exchangeable $\mathrm{K}$ contents in the cultivated than other land use might be due to its continuous losses in the harvested parts of the plants from the cultivated. Previous findings have also considered these factors and the application of acid forming fertilizers as major factors affecting the distribution of $\mathrm{K}^{+}$in soil systems mainly enhancing its depletion especially in tropical soils [34].

Generally, the results show that mean soil exchangeable $\mathrm{Na}^{+}$had no significant differences with land use types $(\mathrm{P}>$ 0.05 ) (Table 3). The concentration of exchangeable $\mathrm{Na}^{+}$was the smallest component on the exchange complex. Although there was no significant differences $(\mathrm{P}<0.05)$ between the soils under all the land use/land cover systems., soils under the forest land use system had the highest mean soil exchangeable $\mathrm{Na}^{+}$concentrations $(0.84 \mathrm{cmol}(+) / \mathrm{kg}$ soil $)$ while those under crop had the lowest concentration $(0.48$ cmol $(+) / \mathrm{kg}$ soil). This may be due to the fact that the low soil $\mathrm{pH}$ under the crop land would lead to a decrease in soil base saturation, through immobilization of the exchangeable bases, and may result in soil exchangeable bases depletion over time [10].

Table 3. Exchangeable bases (Ca, Mg, $K$, and $\mathrm{Na}$ ), $\mathrm{CEC}, \mathrm{EC}$ and percent base saturation (PBS) as influenced by the land uses.

\begin{tabular}{|c|c|c|c|c|c|c|c|}
\hline \multirow{2}{*}{ Land use } & \multicolumn{4}{|c|}{ Exchangeable bases (cmolc kg-1) } & \multirow{2}{*}{ CEC } & \multirow{2}{*}{ PBS (\%) } & \multirow{2}{*}{ EC (dsm1) } \\
\hline & $\mathrm{Ca}$ & Mg & $\mathrm{Na}$ & $\mathbf{K}$ & & & \\
\hline Forest & $60 \mathrm{a}$ & $11 \mathrm{a}$ & $0.8 \mathrm{a}$ & $2.13 \mathrm{a}$ & $75 \mathrm{a}$ & $99 \mathrm{a}$ & $0.023 \mathrm{a}$ \\
\hline Grazing & $38 b$ & $12 \mathrm{a}$ & $0.67 \mathrm{a}$ & $1.3 \mathrm{~b}$ & $57 \mathrm{~b}$ & 91 & $0.017 \mathrm{a}$ \\
\hline Eucalyptus & $21 \mathrm{c}$ & $7 \mathrm{~b}$ & $0.6 \mathrm{a}$ & $0.9 \mathrm{~b}$ & $49 c$ & $63 b$ & $0.014 \mathrm{a}$ \\
\hline Crop & $14 \mathrm{c}$ & $5 c$ & $0.5 \mathrm{a}$ & $0.9 \mathrm{~b}$ & $35 \mathrm{c}$ & $62 b$ & $0.018 \mathrm{a}$ \\
\hline $\operatorname{LSD}(0.05)$ & 17 & 4 & 0.58 & 0.5 & 17 & 22 & 0.031 \\
\hline $\mathrm{CV}(\%)$ & 31 & 31 & 55.9 & 23 & 20 & 17 & 112 \\
\hline
\end{tabular}

\section{Summary and Conclusions}

The conversion of natural forests to crop production and continuous and intensive cultivation of soils without optimum inputs have been practiced in the study area over many. Population pressure has also led to cultivation of marginal lands and steep slopes. The results of this study are evidences of significant changes in the quality of the soils in the Study area. The influence on most parameters was negative on soils of the cultivated land following the removal or destruction. $\mathrm{PH}$ and $\mathrm{OM}$ significantly reduced from 6.4 to 5.6 and from 8.1 to $3.8 \%$ in the forest to cultivated soils, respectively. The soil of the cultivated land was moderate acidic Whereas EC, Total porosity, Exchangeable sodium and Carbon nitrogen ratio showed non-significant $(\mathrm{P}>0.05)$ differences due to land use changes. Total nitrogen decreased from 0.4 to 0.19 in forestland to the cultivated land soils. The amount of exchangeable basic cations decrease and resulting in limitation of growth of most crop plants and ultimately to decline in crop yields and productivity. Land use successions reduced Cation exchange capacity and percent base saturation contents from 75 to 35 and from 99 to $62.6 \%$ in the forest to the cultivated land soils, respectively. As would be expected, the largest and smallest figures were observed in the forest and the cultivated land soils, respectively. This has tremendous implications for agricultural production and soil degradation, which ultimately, to diminished soil fertility and land productivity. Soil CEC is crucial in soil fertility because the total quantity of nutrients available to plants as exchangeable cations depends on it, and it influences the degree to which $\mathrm{H}$ and $\mathrm{Al}$ ions occupy the exchange complex, and thus affects the $\mathrm{pH}$ of soils. On the other hand, the available $\mathrm{P}$ content under the cultivated land was highest (4.40 mg kg-1) compared to the other adjacent land use systems, and this might be due to application of inorganic $\mathrm{P}$ fertilizer in to crop fields. These variations of soil physicochemical properties between land use types indicate the risk to the sustainable crop production in the area.

Therefore, to maintain sustainable agricultural production problems on the watershed need to be alleviated through sufficient knowledge on the properties of soils is prerequisite for designing appropriate management strategies and thereby solving many challenges that the Ethiopians are facing in the crop and livestock production sectors and in their efforts of natural resource management for sustainable development. Generally, it is recommended that different integrated land management should be practiced to different land use systems to overcome land degradation and achieve sustainable agricultural production in cultivated lands of the study area. Moreover, attention should be given to afforestation schemes to combat land degradation and contribute towards mitigating climate change.

\section{References}

[1] Abbasi, M. K., \& Tahir, M. M. (2012). Economizing nitrogen fertilizer in wheat through combinations with organic manures in Kashmir, Pakistan. Agron. J., 104, 169-177. https://doi.org/10.2134/agronj2011.0264.

[2] Arévalo-Gardini, E-, Canto, M., Alegre, J., Loli, O., Julca, A., \& Baligar, V. (2015). Changes in Soil Physical and Chemical Properties in Long Term Improved Natural and Traditional Agroforestry Management Systems of Cacao Genotypes in Peruvian Amazon. PLoS ONE, 10 (7), e0132147. https://journals.plos.org/plosone/article?id=10.1371/journal.po ne. 0132147.

[3] Ayoubi S, Khormali F, Sahrawat KL, Rodrigues de Lima AC. (2011). Assessing impacts of land use changes on soil quality indicators in a loessial soil in Golestan province, Iran. Journal of Agriculture Science Technology 13, 727- 74 https://www.researchgate.net/publication/265979198_Assessi ng_Impacts_of_Land_Use_Change_on_Soil_Quality_Indicato rs_in_a_Loessial_Soil_in_Golestan_Province_Iran. 
[4] Brady, N. C., and R. R. Weil, 2002. The Nature and Properties of Soils. 13th Ed. Prentice-Hall Inc., New Jersey; USA. 960p https://www.pearson.com/us/higher-education/product/BradyNature-and-Properties-of-Soils-The-14thEdition/9780132279383.html.

[5] Brown S and Lugo AL (1990). Effect of forest clearing and succession of the carbon and nitrogen content of soils in Puerto Rico and US Virgin Islands. Plant and Soil 124 53-64. https://www.jstor.org/stable/42938486? seq $=1$.

[6] Chama E. V, and W Murphy., 2007. Soil, their properties and management, $3^{\text {rd }}$. edition, Oxford University Press, Australia changes due to pasture installation in Rondonia, Brazil. Geoderma 70 63-81 https://horizon.documentation.ird.fr/exldoc/pleins_textes/pleins_textes_7/b_fdi_53-54/010016060.pdf.

[7] Chemada, M., Kibret, K., Fite, T., 2017. Influence of different land use types and soil depths on selected soil properties related to soil fertility in Warandhab Area, Horo Guduru Wallaga Zone, Oromiya, Ethiopia. International Journal of Environmental Sciences and $\begin{array}{llll}\text { Natural } & \text { Resources } & 4 & \text { (2): } \\ & 555634\end{array}$ https://juniperpublishers.com/ijesnr/pdf/IJESNR.MS.ID.555634.pdf.

[8] Chen GX, Yu KW, Liao LP and Xu GS (2000). Effect of human activities on forest ecosystem: $\mathrm{N}$ cycle and soil fertility. Nutrient Cycling in Agro ecosystems 57 45-54. https://ink.springer.com/article/10.1023/A: 1009880708469.

[9] Coxhead I and ygard R (2008). Land Degradation. Submitted for Copenhagen Consensus Comments. University of Wisconsin-Madison and Norwegian University of Life Sciences. https://jdmlm.ub.ac.id/index.php/jdmlm/article/view/568.

[10] Eyayu M, Heluf G, Tekaliign M and Mohammed A. "Effects of land-use change on selected soil properties in the Tera Gedam Catchment and adjacent agro ecosystems, north-west Ethiopia”. Ethiopian Journal of Natural Resources. 11 (1): 3562 , 2009. http://www.sciencepublishinggroup.com/journal/paperinfo.asp $\mathrm{x}$ ?journalid=119\&doi=10.11648/j.aff.20130205.11.

[11] FAO, 1995a. Planning for sustainable use of land resources: Towards a New Approach. Land and water bulletin 2. Food and Agriculture Organization, Rome, Italy, 60pp Fisheries 2 (5) 177-183. http://www.fao.org/3/v8047e/v8047e00.htm.

[12] Gebreyesus, B. T.: Soil quality indicators response to land use and soil management systems in Northern Ethiopia's catchment, Land Degrad. Develop. Published online, doi: 10.1002/ldr.2245, https://onlinelibrary.wiley.com/doi/abs/10.1002/ldr.2245

[13] Geissen, V., Guzman, G. M. (2006). Fertility of tropical soils under different land use systems-a case study of soils in Tabasco, Mexico. Applied Soil Ecology, 31, 169-178 https://www.researchgate.net/publication/327384554_Fertility _of_tropical_soils_under_different_land_use_systemsa_case_study_of_soils_in_Tabasco_Mexico.

[14] Geist, H. J. and E. F. Lambin., 2002. Proximate causes and underlying driving forces of tropical deforestation. Bioscience, 52 143-150. https://academic.oup.com/bioscience/article/52/2/143/341135

[15] Gong, J. L., Chen, N. F., Huang, Y, Huang, Z., \& Peng, H. (2005). Effect of land use on soil nutrients in the Loess Hilly Area of the Loess Plateau, China. Land degradation and $\begin{array}{llll}\text { Development, } & 17 & \text { (5), } & 453-465\end{array}$ https://onlinelibrary.wiley.com/doi/abs/10.1002/ldr.701.
[16] Heluf Gebrekidan and Wakene Negassa. (2006). Impact of land use and management practices on chemical properties of some soils of Bako area, western Ethiopia. Ethiopian Journal

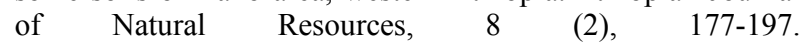
https://www.researchgate.net/publication/309367691 Impacts _of_Land_Use_Types_on_Selected_Soil_PhysicoChemical_Properties_of_Loma_Woreda_Dawuro_Zone_Sout hern_Ethiopia.

[17] Henrik H, Gaetan D, Brigitte B and Christian M (2010). Negative or positive effects of plantation and Intensive forestry on biodiversity: A matter of scale and perspective. $\begin{array}{lllll}\text { Forestry } & \text { Chronicles } & 86 & \text { (3) 354-364. }\end{array}$ https://www.researchgate.net/publication/45794840_Negative _or_positive_effects_of_plantation_and_intensive_forestryon _biodiversity_A_matter_of_scale_and_perspective.

[18] Karltun, E., Lemenih, M., and Tolera, M.: Comparing farmers perception of soil fertility change with soil properties and crop performance in Beseku, Ethiopia, Land Degrad. Develop. 24, 228-235, 2013 https://onlinelibrary.wiley.com/doi/abs/10.1002/ldr.1118.

[19] Kim H. S, H. Anderson, P. P Motavalli, C. J Gantzer., 2010. Compaction effects on soil maeropore geometry and related parameters for arable field. Geodema, 160: 244-251 https://academicjournals.org/journal/SRE/article.

[20] Lemma, B., Berggren, D., Nilsson, I., Olsson, M., 2006: Soil carbon sequestration under different exotic tree species in the southwestern highlands of Ethiopia. Geoderma 136: 886-898. doi: 10.1016/j.geoderma.2006.06.008.

[21] Marks PL and Bormann FH (1972). Revegetation following Forest Cutting: Mechanisms for Return to Steady-State Nutrient Cycling. Science 176 914-915. https://science.sciencemag.org/content/176/4037/914/tabarticle-info.

[22] McLaughlin JW, Liu G, Jurgensen MF and Gale MR (1996). Organic Carbon Characteristics in a Spruce Swamp Five Years after Harvesting. Soil Science Society of America Journal 60 1228-1236. DOI: 10.1126/science.176.4037.914.

[23] MoARD (Ministry of Agriculture and Rural Development) (2010). Ethiopia's Agricultural Sector Policy and Investment Framework (PIF) 2010-2020. Draft Final Report. Pp1-15. https://www.agri-learning-ethiopia.org/wpcontent/uploads/2015/10/Agriculture-Policy-MTR_FINAL.pdf.

[24] Nair KM and Chamuah GS (1988). Characteristics and Classification of Some Pine Forest Soil of Meghalaya. Journal of the Indian Society of Soil Science 36 142-145. https://www.researchgate.net/publication/322288098_Charact erizations_of_Soil_at_Different_Landforms_in_Hilly_Areas_ of_Meghalaya_State.

[25] Olsen, S. R., Watenabe, V. C., Dean, L. A., 1954. Estimate of available phosphorous in soil by extraction with sodium bicarbonate. USDA Circular. No. 939, USA https://www.worldcat.org/title/estimation-of-availablephosphorus-in-soils-by-extraction-with-sodiumbicarbonate/oclc/17316676.

[26] Mulugeta L, Karltun E and Olsson M. "Assessing soil chemical and physical property responses to deforestation and subsequent cultivation in smallholders farming system in Ethiopia". Agriculture, Ecosystems and Environment. 105: 373-386, 2005. https://www.sciencedirect.com/science/article/abs/pii/S0167880 904001501?via\%3Dihub. 
[27] Nigussie, A., Kissi, E., 2012. Physicochemical characterization of nitisol in Southwestern Ethiopia and its fertilizer recommendation using NuMaSS. Global Advanced Research Journal of Agricultural Science 1 (4): 66-73. of soil associated with long term annual application of cattle feed lot manure. Soil Sci.

161 http:/garj.org/garjas/6/2012/1/4/physicochemical-

characterization-of-nitisol-in-southwestern-ethiopia-and-itsfertilizer-recommendation-using-numass.

[28] Ufot, U. O., Iren, O. B., Chikere Njoku, C. U., 2016. Effects of land use on soil physical and chemical properties in Akokwa area of Imo State, Nigeria. International Journal of Life Sciences Scientific Research 2 (3): 273-278 https://www.researchgate.net/publication/331635586_Effects of_Land_Use_on_Soil_Physical_and_Chemical_Properties_in A Ákokwa_Area_of_Imo_State_Nigeria.

[29] Shukla MK, Lal R, Ebinger M. (2006). Determining Soil Quality Indicators by Factor Analysis. Soil Tillage Research 87, 194-204. https://doi.org/10.1016/j.still.2005.03.011.

[30] Solomon, D., F. Fritzsche, M. Tekalign, J. Lehmann and W. Zech, 2002. Soil organic matter dynamics in the subhumid Ethiopian highlands: Evidence from natural $13 \mathrm{C}$ abundance and particle-size fractionation. Soil Sci. Soc. Amr. J. 66: 969978 https://doi.org/10.2136/sssaj2002.9690.

[31] Sparling, G. P., Schipper, L. A., Hill, R. and Bettjeman, W. (2004) Soil quality monitoring in New Zealand: practical lessons from a six-year trial. Agricultural Ecosystems and Environment 104, 523-534. Spodosol. Soil Science 111 323$329 \mathrm{https} / / /$ doi.org/10.2134/jeq2002.1768.

[32] Tahir, B. A., Ahmed, D. M., Ardo, J., Gafari, A., and Salih, M.: Changes in soil properties following conversion of Acacia Senegala plantation to other land management systems. https://agris.fao.org/agris-

search/search.do?recordID=US201301609859

[33] Vågen, Tor-G. and Winowiecki, L. A.: Mapping of soil organic carbon stocks for spatially explicit assessments of climate change mitigation potential, Environ. Res. Lett., 8, 13, 2013. DOI: 10.1088/1748-9326/8/1/015011

[34] Wakene, N. (2001). Assessment of important physicochemical properties of Nitosols under different management systems in Bako Area, Western Ethiopia. M. Sc. Thesis, Alemaya University, Alemaya, Ethiopia https://scholar.google.com/citations?user=NUZsaq4AAAAJ\& $\mathrm{hl}=\mathrm{en}$

[35] Wakene Negassa and Heluf Gebrekidan, 2004. The impact of different land use systems on soil quality of western Ethiopian Alfisols. In: International Research on Food Security, Natural Resource Management, and Rural Poverty Reduction through Research for Development and Transformation. Deutscher Tropentag-Berlin, $\quad 5-7 \quad$ Oct. 2004 http//www.tropentag.de/2004/abstracts/full/265.pdf

[36] Yeshanew A, Welfgang Z, Guggenbeyer G, Tekalign M. (2004). Soil aggregation, total, and particulate organic matter as affected by conversion of native forests to 26 years continuous cultivation in Ethiopia. 203 pp. https://core.ac.uk/download/pdf/33806396.pdf
[37] Yihenew, G. S. (2002). Selected chemical and physical characteristics of soils of Adet Research Center and its testing sites in northwestern Ethiopia. Ethiopian Journal of Natural Resources, $\quad 4$ (2), 199-215 https://environmentalsystemsresearch.springeropen.com/track/ pdf/10.1186/s40068-015-0027-0

[38] Yimer, F., Abdulkadir, A., 2011. The effect of cropland fallowing on soil nutrient restoration in the Bale Mountains, Ethiopia. Journal of Science and Development 1 (1): 43-51 https://dergipark.org.tr/en/pub/ejss/issue/42410/510744

[39] Yitbarek, T., Gebrekidan, H., Kibret, K., Beyene, S., 2013. Impacts of Land Use on Selected Physicochemical Properties of Soils of Abobo Area, Western Ethiopia. Agriculture, Forestry and Fisheries 2 (5): 177183.https://link.springer.com/article/10.1186/s40068-0160076-Z

[40] USDA, 2008. Bulk density. United States Department of Agriculture (USDA), Natural Resources Conservation Service. Available at (Access date: 17.05.2018): https://www.nrcs.usda.gov/wps/PA_NRCSConsumption/dow nload?cid $=$ nrcs142p2_051591\&ext $=$ pdf

[41] Zhang, F., Tiyip, T., Feng, Z. D., Kung, H. T., Johnson, V. C., Ding, J. L., Tashpolat, N., Sawut, M., and Gui, D. W.: Spatiotemporal patterns of land use/cover changes over the past 20 years in the Middle Reaches of the Tarim River, Xinjiang, China, Land Degrad. Develop., 26, 284-299, 2015. https://iopscience.iop.org/article/10.1088/1755$1315 / 41 / 1 / 012033 /$ meta

[42] Hazelton, P., Murphy, B., 2007. Interpreting soil test results: What do all the numbers mean? CSIRO Publishing. Australia, $52 \mathrm{p}$. https://onlinelibrary.wiley.com/doi/abs/10.1111/sum.12402

[43] Fantaw Yimera, b, Stig Ledinb and Abdu Abdelkadir (2007). Changes in soil organic carbon and total nitrogen contents inthree adjacent land use types in the Bale Mountains, southeastern highlands of Ethiopia. Forest Ecology and Management 242 (2007) 337-342.

[44] Walkley A, and Black C. A. (1934). An examination of different methods for determining soil organic matter and proposed modifications by the chromic acid titration method. Soil Sci. 37: 29-38.

[45] Van Reeuwijk. (2002). Procedures for Soil Analysis (6thEds.). FAO, International soil reference and information Center. 6700 A. J. Wageningen, Netherlands.

[46] Soil science: Methods \& applications D. L. Rowell, Longman Scientific \& Technical, Longman Group UK Ltd, Harlow, Essex, UK (co-published in the USA with John Wiley \& Sons Inc. New York), 1994, $x+350$ pp £19.99 ISBN 0-592-087848.

[47] Getachew A., Gete Z., Dejene A., and Shahidur R.(2012). Fertilizer and soil fertility potential in Ethiopia: Constraints and opportunities for enhancing the system. Affiliation: International Food Policy Research Institute. Washington DC. $66 \mathrm{pp}$.

[48] Black, C. A. (19650. Methods of soil analysis Part 2, Am. Soc Agronomy. Madison, Wisconsin, U.S.A. 